\title{
Os trabalhadores e o New Deal
}

Janes Jorge ${ }^{*}$

LIMONCIC, Flavio Os inventores do New Deal: Estado e sindicatos no combate à Grande Depressão. Rio de Janeiro: Civilização Brasileira, 2009.

Palavras-chave: New Deal, sindicatos, Estado.

Keywords: New Deal, Unions, State.

Emilia Viotti da Costa, historiadora brilhante que passou a lecionar nos Estados Unidos em decorrência do clima de brutalidade e medo que se instalou no Brasil na época da ditadura militar, certa vez disse estranhar o fato de um grande número de brasileiros irem àquele país estudar a história do Brasil, ao invés de aproveitarem a oportunidade para conhecerem a própria história estadunidense, pouco conhecida dos brasileiros. Um exemplo de quão fecundo e crítico pode ser o conhecimento da história dos Estados Unidos é o livro de Flávio Limoncic, Os inventores do New Deal: Estado e sindicatos no combate à Grande Depressão, publicado pela Civilização Brasileira em 2009.

O livro é versão de tese de doutorado, defendida, em 2003, no Programa de PósGraduação em História Social do Instituto de Filosofia e Ciências Sociais da URFJ, e tornou-se bastante oportuno em decorrência da crise instalada na economia mundial desde 2008. É provável que muitos leitores sintam-se atraídos, assim, pela sua atualidade. Nesse sentido, já no texto da orelha, Barbara Weinstein da New York Unversity, apresenta um paralelo instigante, indicando que o período anterior à crise de 1929 foi marcado pela concentração de riqueza nos Estados Unidos, com os trabalhadores enfrentando salários estagnados e freqüentes demissões, situação que se repetiu na era Bush.

O estrago da crise de 2008, ainda em andamento e não totalmente avaliado, é incerto, mas, em 1933, quando Franklin D. Roosevelt assumiu a presidência dos Estados Unidos, o Produto Interno Bruto do país correspondia a 56\% do PIB de 1929 e 25\% dos

\footnotetext{
* Doutor em História pela USP e professor da Universidade Federal de São Paulo.
} 
trabalhadores estavam desempregados. Roosevelt, eleito com o discurso de debelar a crise, punir os empresários gananciosos e oferecer proteção social aos "homens esquecidos" seria reeleito em 1936, 1940 e 1944, falecendo em 1945. Em sua longa no poder foi cultuado por amplas parcelas da sociedade estadunidense, tendo retratos seus afixados nas repartições públicas, sindicatos e lares das famílias trabalhadoras, recebendo cartas e cartas de toda parte do país. O New Deal renovaria o próprio universo artístico dos EUA, promovendo inovações estéticas e temáticas que exaltavam os trabalhadores e a coletividade. No Brasil de Getúlio Vargas, como é sabido, ocorria algo semelhante, e uma de suas melhores intérpretes, Ângela de Castro Gomes, fez parte da banca de doutorado de Limoncic.

Contudo, mesmo sem essa inesperada atualidade provocada pela crise econômica mundial, há razões de sobra para ler e discutir a obra de Flavio Limoncic. Talvez uma das principais seja que se trata de um ótimo começo para aqueles que pretendem entender os Estados Unidos. Afinal, ao analisar a relação entre Estado e sindicatos nos anos 1930 e 1940, Limoncic reconstitui a própria formação da classe trabalhadora do país desde o século XIX, seus valores, interesses e lutas. E acompanhar a formação da classe trabalhadora revela muito daquilo que é fundamental na história da maioria dos países.

O livro passa em revista à historiografia estadunidense sobre o trabalho, a Grande Depressão e o New Deal. Aqui, vale ressaltar a crítica do autor à historiografia que promoveu a idéia de que a sociedade estadunidense teria se desenvolvido tendo como base um consenso fundamental entre as diferentes classes e grupos sociais, o que afastara questionamentos profundos sobre o desenvolvimento do país. Plasmada nos anos 1950, quando a confluência de ganhos decorrentes de uma fase de grande prosperidade econômica, propaganda ideológica e repressão, levou a classe trabalhadora dos EUA a um período de acomodação, a historiográfica do consenso projetou a situação dos anos 1950 para o passado, colocando nas sombras, assim, os movimentos trabalhistas que propugnaram mudanças radicais ou que lutaram radicalmente para que as mudanças percebidas como ameaça não ocorressem. O próprio assalariamento era visto, por muitos trabalhadores, como algo equivalente à escravidão no século XIX.

A idéia de um consenso fundamental nos Estados Unidos ruiu nos anos 1960, época das mais tensas e criativas no país. A luta contra a Guerra do Vietnã, pelos direitos civis, por igualdade de gênero, a consciência dos problemas ambientais, os assassinatos de lideranças 
políticas e sociais, tudo isso fez com que a imagem de uma nação sem conflitos implodisse. Em meio a esse contexto, aparece a nova história americana do trabalho, sob a inspiração da historia social inglesa - Christopher Hill, Eric Hobsbawm, Raymond Willians e E. P. Thompson. Desde então, emergiu uma classe trabalhadora extremamente heterogênea seja por suas origens, composição étnica, situação no mercado de trabalho e orientação ideológica, com dificuldades para forjar uma identidade comum em um país continental e diverso, mas igualmente marcada em seus atos e palavras, por uma vontade de reformas ou mesmo utopias anticapitalistas - fossem religiosas, comunitárias, anarquistas ou socialistas.

O ponto central dos Inventores do New Deal é o que o autor chama de "crise de regulação concorrencial do capitalismo", que tinha na contratação individual do trabalho um de seus elementos centrais. Com Roosevelt torna-se hegemônico o entendimento de que emprego, produção e consumo deveriam ser regulados a partir da intervenção do Estado, não mais pelo "livre mercado" como preconizava o ideário liberal hegemônico nos EUA, mas incapaz de superar a Grande Depressão. No plano sindical isso significava instaurar a contratação coletiva do trabalho, utilizando, para isso, o National Labor Relations Board, criado em 1935, agencia que passava a interferir na própria organização dos sindicatos e em sua relação com o patronato. A lógica de tal medida na superação da crise era de que a contratação coletiva iria aumentar os rendimentos da classe trabalhadora ao fortalecer seu poder de barganha. Com melhores salários, os trabalhadores poderiam consumir mais, aumentando a demanda por produtos industriais e agrícolas, retirando a indústria estadunidense da estagnação. Até então, o que ocorria era o inverso. As empresas, competindo ferozmente, procuravam reduzir os custos de produção, especialmente, depreciando os salários que praticavam.

Dessa forma, a partir do New Deal, os sindicatos deixavam de ser vistos como agentes de interesse privado, organizados sem a interferência do Estado, e tornavam-se agentes do interesse público, com o Estado interferindo nas relações entre capital e trabalho, tendo em vista o interesse maior da sociedade. Dessa forma, encontra-se aqui uma problemática parecida com a que o Brasil e outros países viviam no período e coloca-se em discussão o corporativismo e a possibilidade de se organizar em bases democráticas.

Flávio Limoncic centrou seu estudo nos trabalhadores da indústria automobilística fundamental na configuração da sociedade estadunidense. A conquista da sindicalização na 
Ford é uma das partes mais empolgantes do livro e assinala a vitória decisiva do ideário renovador e pró-trabalhista do New Deal. Significou a derrota de Henri Ford, inimigo declarado e ativo dos sindicatos, que reprimia por todos os meios a sindicalização de seus empregados, sendo conhecido como o "Mussolini de Detroit", e que possuía correspondida admiração por Hitler - embora seja preciso lembrar também que o processo de racionalização da produção conhecido como "fordismo" entusiasmou pessoas da esquerda à direita, desde que, entusiastas da industrialização.

Acompanhar a luta dos trabalhadores urbanos dos EUA inevitavelmente nos leva a pensar no que ocorria no campo. Talvez algum outro pesquisador brasileiro, animado com o êxito de Limoncic, venha pesquisar esse tema tão importante. Por hora, basta lembrar que foram intensos os conflitos envolvendo trabalhadores rurais na costa leste, região marcada por grandes propriedades, agricultura irrigada (e subsidiada) e mão de obra super explorada - situação revelada aos EUA, em 1939, por dois escritores californianos, John Steinbeck e Carey McWilliams. Igualmente oportuno e original quando se pensa em pesquisas sobre movimentos sociais é a análise de Flavio Limoncic referente à atuação do poder judiciário na repressão aos trabalhadores, pois os sindicatos dos EUA tinham nos tribunais um de seus mais terríveis inimigos.

O livro termina indicando a revanche dos liberais e do grande capital no pós-guerra, que passaram a atuar de forma agressiva e sistemática contra o que consideravam uma interferência desmedida do governo e dos sindicatos na sociedade, desmontando o que havia de mais transformador no New Deal, em especial, a concepção, ainda incipiente, mas fundamental, de que os trabalhadores teriam um papel ativo na organização e no planejamento da economia da nação mais rica do mundo.

Recebido em 08/12/2009.

Aprovado para publicação em 20/12/2009. 